\title{
Responsible talent management: towards guiding principles
}

\section{Purpose}

This article addresses three concerns about the operationalization and possible effects of exclusive talent management; the core assumptions that underpin and shape talent practices, the problem of fair talent identification, and potentially adverse employee reactions.

\section{Design}

This is a conceptual paper that integrates empirical research on talent and talent management with ideas from business ethics.

\section{Findings}

Organizations should not simply assume that they meet the underlying assumptions of talent management. Where the assumptions can reasonably be shown to be valid, then a framework based on a set of principles is suggested to guide organizational approaches towards responsible talent management.

\section{Practical implications}

The article provides talent practitioners with a set of principles, or at least some substantive suggestions, to be considered in the design of socially responsible talent management programmes and in programme evaluation.

\section{Social implications}

The article provides guidance for organizations wishing to improve the care of their workforce in relation to strategies of employee differentiation based on performance and potential.

\section{Originality/value}

Despite the burgeoning literature on talent management the topic has not received much attention from an ethical and socially responsible viewpoint. This article adds to that literature and suggests further research particularly concerning the existence of real talent differences on which the entire talent management project is based.

Article type: Conceptual paper

Key words: talent management; business ethics; social responsibility; 


\section{Introduction}

Organizational talent management (TM) is a contemporary manifestation of long-standing corporate interests in management and leadership development (eg., see Derr et al.,1988;

Dooher and Marquis, 1952). Emerging from this long tradition, the specific idea of managing 'talent' accelerated in the 1990s and has evolved to include new lines of research concerning exclusive talent management (O’Connor and Crowley-Henry, 2019), global talent management (King, 2015; Schuler et al., 2011), strategic talent management (Collings and Mellahi, 2009) and inclusive talent management (Swailes et al., 2014).

At the heart of TM (although not inclusive TM) is the simple idea of identifying high potential employees, training them well and placing them in influential positions where they can best impact on organizational performance (Collings et al., 2017, p.5). This practice has become known as exclusive (or elitist) TM given its exclusive treatment of small groups and its exclusionary treatment of the majority of the workforce. Exclusive TM is closely connected to strategic and global TM and carries with it a range of moral issues and practical concerns. These concerns are examined in this article which introduces another turn in the TM literature; towards responsible talent management (RTM).

Of particular importance for any consideration of RTM are the assumptions on which exclusive TM practices are based. Three core assumptions are suggested here. First, that senior managers, often aided and abetted by HR advisors and management consultants, assume that the talented exist; that a small proportion of their workforce has much more leadership potential than the rest. Second, that this small proportion of talented people can be identified reliably and fairly. Third, that corralling the talented into talent pools, giving them accelerated and advanced development opportunities and then deploying them in key positions improves individual and organizational performance. These assumptions are 
plausible and may, in a given organizational space and time, be valid. However, they are distinctly managerialist in nature and they should not be taken as truisms. If any of these assumptions fails, particularly the first or second, then the validity and moral standing of a talent programme are called into question.

In addition to examining these assumptions, in mapping out a terrain for RTM it is necessary to account for the darker sides of exclusive TM which should trouble the moral organization. One area concerns the problems surrounding talent identification. Exclusive TM relies upon judgements about individuals; their past, present and future worth. Even if the judgements are safe, at the least this approach can be criticised for treating people as little more than disposable resources (Painter-Morland et al., 2019). Over and above this moral objection, the search practices used in exclusive TM can be gendered in ways that disadvantage women (Festing et al., 2015). Furthermore, talent identification runs the risk of becoming a highly politicized practice in which personal interests and power considerations overshadow genuine talent-based differences between competing individuals. The second broad area of concern is around the adverse effects of talent status and talent pools on participants and nonparticipants. While TM can boost the careers of some participants it can harm others through career derailment, division and adverse psychological outcomes (Dalal and Nolan, 2009; Ross, 2013). Although these potential downsides are not inevitable, they do have empirical support. They are not just theoretical.

A further area of concern is that, despite credible theoretical underpinning and logical extrapolation from the links between high performance work practices and performance (Combs et al., 2006), the evidence that exclusive TM actually boosts firm performance is at best modest (Collings, 2015). Taken together these various shortcomings generate a range of ethical tensions (Painter-Morland et al., 2019). In combination, the key assumptions of TM coupled with known evidence-based fallout present challenges for the moral organization. 
The challenges are not insurmountable however, and organizations pursuing exclusive talent strategies need to do so based on assumptions that are valid in their specific context and adopt practices that aim to either reduce or eliminate potentially adverse effects. Largely missing from the TM literature, however, is a treatment of how organizations can approach this challenge. As such, and in introducing the notion of responsible talent management and a set of principles to guide practice, this article contributes to a framework that, hopefully, will help TM practitioners implement more ethical and morally sound talent practices.

The article next considers the meaning of talent in exclusive TM to clear the ground for subsequent analysis. The main assumptions on which exclusive TM is based are then interrogated in some depth. Possible problems arising in TM implementation are then considered. The key contribution is to offer a set of principles that can help organizations implement and sustain responsible approaches to managing talent and that has the potential to help with the evaluation of talent programme design and operation.

\section{Talent and talent management}

Unless talent management is defined as something distinct from HRM or management development then the term has little distinctive utility. To ground the arguments in this article the definition of TM provided by Collings et al. (2017) is adopted; namely the development of high performing, high potential employees using a distinctive development architecture to ensure that key positions in the organization are filled with competent and committed people. With the exception of inclusive TM, research in the field seems to be coalescing around this definition (Collings et al., 2017; Gallardo-Gallardo et al., 2015; Thunnissen and Gallardo-Gallardo, 2019).

If this is exclusive TM, then what is talent? The definition, above, implies that talent is treated as a combination of high performance and high potential for advancement in the same 
field or elsewhere. Underpinning high performance are combinations of skills, knowledge and characteristics that enable some people to outperform others. In organizational contexts, on the face of it, talent equates to the abilities of people or at least is highly correlated with abilities. The mechanisms and interactions that lead to these abilities being present in an individual and to their flourishing in a particular workplace at a particular time are, however, complicated and are not taken further here unless otherwise noted. For the purposes of exclusive TM, talent is typically treated as a simple combination of performance and promotion potential, perhaps with more emphasis on potential.

Two alternative views of talent are worth noting at this point, however. First is the distinction between talent as properties of individuals (their abilities) and talent as individuals per se (Gallardo-Gallardo et al., 2013). In modelling the links between talent and economic development, talent as a property of individuals can be proxied by levels of education, occupational types and as underlying skill (Florida and Mellander, 2018).

Second, is the idea of innate talent based on genetic and neurophysiological characteristics that suit a particular domain and which when coupled with extensive practice enable superior performance in that domain. Although there are debates around the existence of innate talent and whether practice alone is sufficient for superior performance (Hambrick et al., 2016; Howe et al., 1998) the balance of opinion is that it does exist (Baker and Wattie, 2018; Simonton, 2017; Ward et al., 2017). If so, this is the purest form of talent but its biological composition remains far from our understanding. Some implications arising from a greater appreciation of innate talent in organizational contexts are considered in Swailes (2020).

For organizational TM in general and for the purposes of this article therefore, talent, unless otherwise stated, refers to the abilities that individuals have and which they are perceived to 
have. The talented, by implication, are groups of people who have or who are perceived to have above average abilities; how far above average rests with organizations to decide.

\section{Assumption 1: The existence of the talented}

The first core assumption is that the talented exist as a viable and distinctive workforce community; as a distinctive stakeholder group (Swailes, 2013). Distributions of talent in society have been widely assumed for some time as illustrated by Durkheim's ideas that people have equal rights to fulfil their talents and that unequal treatment of people is justified because some have greater talent than others (see Green, 1989). In coming to his influential Theory of Justice, Rawls (1971) accepted that people have differing talents that occur by chance and that it is in the interests of the lesser talented that resources are diverted to the greater talented. Talent (as skills or qualifications) is widely assumed to link to economic growth on the grounds that more talented people come to 'organize production by others, so they can spread their ability advantage over a larger scale' (Florida, 2002; Murphy et al., 1991, p. 503).

At the organizational level, this assumption is currently fuelled by continuing narratives of talent shortages emanating from international consulting organizations (eg. see ManpowerGroup, 2018; SHRM 2019). There is a potential flaw here, however, in that consultants' narratives usually use 'talent' as a general term to mean skilled employees in labour markets and speak of the difficulties that firms face in finding specific skills (eg. engineering) as shortages. Localised skills shortages are well known and in this respect talent shortages do exist, but it should not be taken to fuel speculation that the workforce in an organization is short of high performing and/or high potential people. It may be short of a specific skill set, but that is not the same. Nevertheless, organizational belief in talent is evidenced by Oxford Economics (2012) who found that between 60 and 70 per cent of firms 
globally intended to focus more on workforce segmentation and in particular on formally identifying top performers, key roles and high potential employees.

In order to quantify the extent that the talented might exist, one rule of thumb used in talent and giftedness research is that the talented represent the top 10 per cent of age peers in terms of ability in a domain (Gagné, 2013). If employee performance in an organization follows a normal distribution, then the top 10 per cent contains all those employees whose performance rating is greater than 1.3 standard deviations above the mean. Most people are around the average - 68 per cent are within one standard deviation of the mean. A recent survey found that on average firms following an exclusive approach classified seven per cent of their employees as talented (Boštajančič and Slana, 2018). One of the difficulties with this approach is that in organizational contexts, unlike sport or music, it is not clear what the domain is in which talent is being measured. Talent for what, precisely. Complicating this question is that talent is often seen as part performance, part potential and the metrics used to measure potential are more subjective than those used for performance (Silzer and Church, 2009).

Normal distributions, however, may not be representative of performance in many settings. Recent work on the contributions of 'stars' in several occupations suggests that a large proportion of value added comes from a small number of employees (Joo et al., 2017). Rather than following a normal distribution, performance can follow a power law or Paretian distribution in which a small number of people deliver a large share of outputs. As such, these findings are highly supportive of the first assumption. However, more work is needed on performance in mainstream workplaces to establish how widely power law distributions are found. Another possible problem with relying too much on power law distributions is that recent modelling of talent and outcomes (Pluchino et al., 2018, p.23) suggests that over the course of a career luck, or chance, plays a considerable role in the distribution of outcomes 
over and above talent and that 'the most successful agents are almost never the most talented ones'. The role of luck, or more particularly the ability to capitalise on chance events, should not be underestimated in determining career outcomes (Grimland et al., 2012). If this is the case, then what appears to be talent may be little more than an average employee who has had the benefit of luck or one who has the talent to use it.

Another consideration that supports the first assumption comes from recent advances in understanding how talent evolves in people. In particular, the idea that talent takes time to develop. Different traits develop at different speeds and times such that it is only when the necessary traits synchronise with each other in a person that a talent, in parallel with conducive social environments, can flourish (Simonton, 1999). The implication of this is that the more that people engage with different talent domains in a lifetime then the more the chances of encountering a domain that activates a talent are increased (Kaufman, 2013). If this is correct, then organizations should periodically look for 'new' talent since it is not a fixed attribute of people.

In sum, while the existence of the talented in many domains is beyond dispute the existence of a talented class in organizational settings is more problematic even though in many organizations it is clear that some employees are much better performers than others at the same level. Where high performance associates with high ratings of potential then we have the making of a sub-group of employees; the talented. The moral question that arises at this stage is whether an organization is safe to proceed on the assumption that some of its employees are substantially more talented than others and thus more suited to deployment in key positions. If there are no reasonable grounds to consider that some people in a workforce have substantially more talent than others then sifting for talented employees and subsequently devoting resources to them become morally problematic. This leads to Principle 1. 
Principle 1. Actors with interests in establishing exclusive TM programmes should be able to articulate plausible reasons why they believe that some employees have substantially more talent (potential) than others in their specific work contexts.

Principle 1 raises questions around how the various actors can reach conclusions about whether some employees offer much more potential than others and around the criteria on which such judgements are made. Some sort of performance rating scheme that reveals a distribution of performance/potential seems necessary, such as the 9-box grid (eg., see Robinson et al., 2009) coupled with talent reviews. Also pertinent is a consideration of what the purpose of identifying talent would be since, to some extent, talent should be identified in relation to particular organizational challenges. Organizations should be wary of merely acquiescing to pressures emanating from their institutional environment to adopt certain types of human resource management practices (Farndale and Paauwe, 2007). They should also consider, since TM is not apolitical, the range of possible impacts of openly recognising talent, and by implication the use of talent pools, on overall employee relations (see below under Implementation). If these tests are passed, then, in keeping with the definition of exclusive TM (Collings et al., 2017), Principle 1 calls on senior managers to identify which positions/roles have disproportionate impacts on organizational performance and whether the net benefits of implementing talent development programmes are worth having.

\section{Assumption 2: Fair talent identification}

If grounds for a talented 'class' are found, and in many organizations it seems likely that they will be, then the second assumption is that the talented can be fairly and reliably identified. However, given the range of biasing and confounding factors pertaining to assessment of performance and potential there is considerable danger that fairness and reliability will be compromised in light of concerns that performance ratings can do more harm than good (eg. 
see Adler et al., 2016). Specific dangers include impression management by ratees which can inflate performance ratings (Wayne and Liden, 1995; Zivnuska et al., 2004), interpersonal affect which can lead to rater leniency (Tsui and Bruce, 1986), the effects of organizational context in explaining variance in performance ratings (Ellington and Wilson, 2017), the positive or negative influences of a person's previous ratings (Murphy et al., 1985) and contrasting rater/ratee sex effects (Scherer et al,, 1991; Szymanska and Rubin, 2018).

\section{Gendered leadership}

Furthermore, if TM is concerned with finding leadership potential it has to confront and work around prevailing androcentric assumptions and discourses. Ford (2005, p. 247), for instance, argues that mainstream positivist approaches to leadership work to reify 'the very concept of leadership into an objective reality' such that 'hidden masculinist assumptions' become commonplace and this overlooks the importance of taking account of social and cultural contexts and their effects on leadership. What this means is that the notion of talent can be masculinised and talented identities can be created and reproduced such that some groups are privileged and others are overlooked (Makarem et al., 2019).

Rosette, Koval, Ma and Livingston (2016) in studying perceptions that women have low leadership potential and that they receive penalties for counter-stereotypical behaviour found that Black, Asian American and White women were stereotyped in different ways that influence their likelihood of recognition as leaders. Overcoming gender bias is complicated since it is usually impossible to point to single perceptions or organizational structures that cause it such that top-down pressures to reduce bias, for example through policy statements, are compromised (Hogue and Lord, 2007). Hogue and Lord (2007) highlight the complex nature of changing perceptions and suggest interventions such as senior managers advocating cultures of fairness, allowing time for interventions to change embedded structures, not 
assuming that people in senior leadership roles are the right role models or the most appropriate leaders, and not assuming that achieving more balanced proportions of women in leadership roles means that problems have been overcome. The upshot of gendered leadership for RTM is that any descriptions of talent that are produced should be screened for inbuilt even if unintentional masculinity.

\section{Talent as a social construct}

Over and above the possible sources of bias above, there are additional sources that intervene in the social mechanisms through which people are deemed talented or not. Of particular importance is the possibility that talent searching reduces to a poor approximation of true talent though the influence of social distractions. In organizational contexts, talent can take on another shape reaching beyond innate characteristics and beyond the sum of the abilities that they enable; talent becomes the ability to reflect the organization's mission and to capture executive attention. This idea was mooted by C. Wright Mills long before 'talent' became such an influential business concept. Mills (1956 [2000]) was doubtful that managerial talent actually existed but was in no doubt that executives looked for certain traits in their successors. These traits include being generalists not specialists, how people look and would look, how they sound and would sound, looking and sounding as if they will perpetuate the organization, and being talkers and listeners (not readers). For Mills, once above the lower ranks the more it becomes necessary to demonstrate the right "corporate character' (p. 140).

Although giftedness is separate to talent and is generally thought of in relation to younger people (Callahan, 1997), the two concepts are related and giftedness can also be treated as a social phenomenon (Borland, 1997, 2005; Smith and Campbell, 2012). A survey of Canadian students (Parekh et al., 2018) found little association between giftedness and performance, 
strong associations between parental occupation, giftedness and performance, along with race and gender effects. Parekh et al. (2018. p.1) concluded that giftedness was sufficiently socially constructed as to be part of the 'replication of social structures and advantage' and question its use in 'defining and organizing students in schools' (p.1). A link between cultural capital and talent in graduate recruitment was found by Ingram and Allen (2019, p.737) who concluded that employers can 'fall into the trap of assuming that displays of cultural capital evidence knowledge, skills and personal traits'. Echoing Mills, they refer to 'the institutional self' and employers' preferences for people that fit with it (p. 739).

Even if these dangers can be minimised in the preliminary stages of talent identification, then subsequent stages of talent recognition, eg., talent review meetings, are vulnerable to organizational politics and distorted judgements (Hammett, 2008). Zesik (2020), for instance, shows how formal talent review discussions are subsequently underpinned and informed by informal social interactions between decision makers in which new insights are revealed.

\section{Articulating a vision of talent}

As such, where Principle 1 is satisfied and there are grounds for thinking that an organization does contain talented groups it falls upon senior managers to figure out what it means to be talented. Executives should avoid simply extrapolating and projecting views of themselves into a talent description. To be more ethically safe, some sort of open process should be involved so that stakeholders in the talent definition process are represented. The primary outcome should be a vision or visions of talent that match the organization's competitive situation and which can reasonably be fulfilled through fair assessment processes. Hence, Principle 2, Organizations should produce descriptions of talent that are realistic, aspirational, and non-discriminatory that match the various management levels that they are intended to relate to. 
Talent criteria are already used of course (Pruis, 2011; Silzer and Church, 2009) but not universally and some organizations do not disclose talent status to talented employees (Ehrnrooth et al., 2018; Sumelius et al., 2020). Non-disclosure of talent status could indicate that talent criteria are either absent or are sufficiently vague to justify any talent identification decision. Without a transparent description of talent, line managers, HR advisers and executives have more freedom to manipulate and to be manipulated. A danger remains, however, that descriptions of talent can simply reflect social fit rather than true differences in organizational talent. It is important therefore that the criteria for talent/potential are formulated through some sort of open process through which the views of various stakeholders are taken into account (Swailes, 2013). The more open the procedures surrounding programme design are, the more managers' perceptions of procedural justice will increase (Jerusalim and Hausdorf, 2007).

Following from Principle 2, a more challenging principle arises for RTM which concerns the extent to which people can be assessed against the criteria and identified reliably and fairly. Without robust talent identification procedures two dangers arise. First, organizations running exclusive TM do so to the extent that it meets business needs. For this reason in large organizations it may not, from the firm's perspective, be necessary to identify everyone above a talent threshold and there may be practical limits on how many employees can be in talent pools at a particular time to the exclusion of others who are just as good. The more that people who are equally talented and who want to be included are excluded the more morally problematic exclusive TM becomes. Second, the identification process becomes vulnerable to manipulation by political actors which could lead to talented people being excluded and untalented people being included. Hence, 
Principle 3a, Talent identification processes should be inclusive to the extent that all those assessed to be at or above an agreed talent threshold and who want to be included in development programmes are included.

The question arising for executives and HR advisers at this stage, therefore, is what practices are in place to alert the various actors in talent programmes to the nature and effects of conscious and unconscious biasing factors and what practices are in place to minimise their impact on fair and reliable decisions (Noon, 2018). This leads to Principle 3b.

Principle 3b. Organizations should ensure that actors involved in talent recognition are alert to the range of biasing and distorting factors that affect talent identification decisions.

One approach to help reduce inconsistencies is the use of calibration sessions or talent reviews (Henson, 2009; Zesik, 2020). The key point of these sessions is to give key actors access to definitions of potential and the criteria to recognise it along with open forums in which views about individuals are not suppressed.

\section{Assumption 3: Talent management and organizational performance}

If the first and second assumptions hold, then the third test is that organizing the talented into talent pools, providing differentiated development and deploying them in high value adding roles has distinctive effects on competitive advantage that would not have otherwise occurred. The logic of this assumption is widely accepted (Aguinis et al., 2012; Collings, 2015; Garavan et al., 2015; Joyce and Slocum, 2012). The assumption, or something very much like it, seems to hold at national level as, for example, Strenze (2013) found that the efficient allocation of talent (as cognitive ability) boosted the economic growth of American states. 
Following a global survey, Right Management (2014) reported that 30 per cent of senior managers were 'very confident' that their TM activities paid off, 50 per cent were 'somewhat confident' and 20 per cent wanted more 'rigorous measurement of business impact'. This fits with Blass's (2007) observation that firms were concerned with finding useful measures of TM's return on investment. Furthermore, the empirical evidence that TM improves organizational performance is modest at best. At worst it is wrong. Pfeffer and Sutton (2006), for instance, point out that the performance data used to drive the influential 'War for Talent' campaign in the 1990s was collected before, not after, the data on management practices.

In a study of Turkish firms, Glaister and colleagues (2018) found a link between TM practices and subjective firm performance that they explained through the development of social capital and employee networks. Studies of Russian and Chinese firms found positive associations between talent development and firm performance that were explained through better knowledge acquisition and transformation (Latukha and Veselova, 2018; Latukha, 2018). All these studies used cross-sectional methods, however, such that causality cannot be confirmed. The only study using longitudinal data (Son, Park, Bae and Ok, 2018) found a modest increase in innovation and a small increase in employee turnover with increasing levels of TM.

In trying to establish a TM-performance link, the TM field faces the same problems that befell efforts to connect strategic HRM to firm performance and which required a steady accumulation of evidence before positive effects were shown beyond much doubt (Saridakis et al., 2017). While measuring outcome variables such as individual and organizational performance is relatively easy, it is difficult to quantify the independent variable, namely the extent that organizations implement talent management. It should not be treated as a binary variable (present or absent) since TM takes many forms and organizations can implement some TM practices but not others. 
Even if TM is implemented in large part, however, this does not reveal anything about whether the people in the talent pools in a particular organization actually possess any more talent than the rest of the workforce. If net positive effects of TM on organizations are evidenced, then questions remain about whether it is the talent pool or the talent that is making the difference. This arises from the rather counter-intuitive possibility that talent programmes may benefit organizations even if populated by people with only average talent. This could occur from Pygmalion-like effects (Eden, 1984; Swailes and Blackburn, 2016) which occur when people who know they have been identified as having potential respond to the differentiated encouragement and experiences provided to them and outperform others even though they have no additional ability. This suggestion gets to the heart of TM since it questions the extent to which it is superior talent or the talent programme or some interaction between them that, presumably, connects to better organizational performance.

Furthermore, the association between a single high performance work practice and organization-level performance will be difficult to detect given the wide range of factors that affect performance measurement; single respondents, cross-sectional data, and lag effects amongst other methodological problems. On its own, the measurable effects of TM seem likely to be small, and thus hard to detect, but will be more effective when bundled with other high performance work practices (Combs et al., 2006).

While the field waits for confirmatory evidence of TM's positive effects, it appears that it is based more on fashion and faith than empirical findings (for an extensive treatment of this idea see Rotolo et al., 2018). If executive faith is to be upheld then it is necessary for talent programmes to be implemented with a clear objective (Pruis, 2011) such as succession planning and filling key positions or tackling specific organizational challenges (Adebola, 2019). If there is no clear shared purpose for a talent programme then the dangers of strategic drift and of arbitrary talent identification increase. This leads to Principle 4, 
Principle 4. Key actors in talent system design should be able to articulate the mechanisms through which programmes connect to organizational goals.

\section{To operationalise this principle, organizations could work back from strategic plans to explain how talent programmes fit with and will contribute to particular targets, aims,} objectives and priorities. Across organizations, strategic goals will be many and varied and executives should be able to demonstrate how the intended talent programmes connect to the individual-level and organizational-level outcomes that are required if goals are to be met. Executives and talent managers should be able to explain the ways in which an extant or proposed talent programme will support performance. Without convincing explanations of programme fit, questions inevitably remain surrounding the true intent of a programme and its relevance to the organization's competitive position.

\section{Programme implementation - implications for RTM}

A recent review of empirical research on employee reactions to talent status (De Boeck et al., 2018) found only a small positive effect of TM on affective reactions, medium to large positive effects on behavioural outcomes alongside some evidence for negative affective reactions such as stress, anxiety and uncertainty. De Boeck et al. (2018) conclude that it is unsafe to assume that people granted talent status will always react positively and call for more research into the boundary conditions surrounding employee reactions. The ways in which the talented and non-talented perceive procedural and distributive justice are strong theoretical influences on their reactions and engagement (Gelens et al., 2013; O'Connor and Crowley-Henry, 2019).

Identification as talent raises a person's visibility but also places them in a spotlight with accompanying risk. Ethnographic research (Daubner-Siva et al., 2018) has shown how the initial boost from talent recognition can be short-lived particularly when 'the organizational 
context changes and behaviours that first led to success become redefined as problematic' ( $\mathrm{p}$. 83). This finding illustrates how initial recognition as talent can raise expectations which if not subsequently fulfilled can lead to breach of the psychological contract and subsequent unwanted behaviour such as job search (Dries and De Gieter, 2014). The pressure to conform to the expectations of others in order to be successful has been labelled the curse of talent management (Peteriglieri and Peteriglieri, 2017) and forms part of an identity struggle in a competitive arena that can lead to possible negative outcomes (De Boeck et al., 2018). In light of potential adverse effects arising from receipt of talent status two further principles arise,

Principle 5a, Actors planning to implement exclusive talent programmes should assess the nature, the sources and the scale of adverse impacts and assess their likelihood of affecting participants.

Principle 5b, Organizations should monitor the progress and well-being of talent pool participants.

Principle 5a asks organizations to think-through the possible effects of a talent programme at the design stage. Programmes need to be visible, so questions should be asked about how the programme should be packaged and branded to avoid cynical reactions, how inclusive or exclusive it needs to be, and what employee groups should be covered. To what extent might the operation of a talent programme provide disincentives to employees who feel they have little or no chance of being selected? In making these evaluations, talent practitioners should consider the extent to which differentiation and individualism are part of an organization's culture since sensitivity to differentiation seems likely to be positively related to traditions of collectivism. The balance of potential positive and negative outcomes needs to be carefully weighed before programmes are implemented. 
Principle $5 \mathrm{~b}$ is not simply to monitor progress so that struggling performers are removed in the interests of corporate gain or to figure out who is ready for promotion. Rather, it is necessary so that responsible organizations carry out their duty of care towards employees in potentially stressful situations. It may require that structures are put in place through which individuals can openly and safely discuss their concerns without fear of prejudice. Care should also be taken at preliminary stages to ensure that employees selected for talent pools can navigate them successfully, for example by considering a person's derailment potential (Ross, 2013). A related concept is that of talent sustainability (Pruis, 2011). For example, the talented should not be identified as such without two or three years of above average performance and once identified as talent they should be supported by the organization for at least another two years even in their performance diminishes.

While the talented constitute a clear stakeholder group, assuming that they really are more talented, then organizations should not lose sight of those employees that are overlooked (Swailes and Blackburn, 2016). Hence,

Principle 5c. Organizations should monitor exclusive talent programmes and the configurations around them to assess their effects on employees that are not in talent pools.

Principle $5 \mathrm{c}$ is related to $5 \mathrm{a}$ since the possible demoralizing effects of non-talent status should be evaluated at the design stage. However, it remains important in RTM to assess the wider and evolving effects of programmes in practice and for this purpose organizations are reliant on solid feedback from line managers on how a programme is experienced and perceived at ground level. There are thus implications for the role of line managers in the talent process and in particular their understanding of the philosophy behind a talent programme and of the organization's views of what being talented means. Without such understanding the key role of the line manager in brokering and supporting a talent programme will be undermined. 


\section{Conclusions}

This article has brought together a range of issues and concerns surrounding the practice of exclusive talent management. These concerns arise from questioning the core assumptions upon which exclusive TM is based and from a consideration of problems with talent recognition and of evidence-based adverse effects. Given that the domain in which organizational talent is sought is so poorly specified it is difficult to see how talent can be identified with much precision. There are strong grounds for concluding that talent in many contexts will never be much more than Mills' idea of fitting with the corporate character. However, despite these dangers, talent identification systems may capture some of the most talented employees while overlooking others and including some individuals with relatively little talent. If the development systems are good, then organizations may benefit despite partial and even empty talent identification process. The principles offer concrete steps that will hopefully contribute to more socially responsible and more ethical TM as they can be integrated into the early stages of programme design and later stages of programme evaluation. Organizations can test their intentions regarding talent management against the principles to assess the extent to which particular concepts have been operationalised in programme design. Their consideration should contribute to strengthening the unique talent climate in an organization (King, 2017) and the underlying talent pipeline.

A limitation of the proposed framework is that some of the principles do reflect existing practice although this does not mean that all organizations pursuing TM are using them. For instance, the use of criteria to identify potential is central to TM (Silzer and Church, 2009) but they are not necessarily used. In addition, the principles of RTM are not proposed in order to bolster financial performance although adopting them should lead to better ethical performance and better employee relations as far as talent programmes are concerned. However, when coupled with more accurate talent identification and duty of care towards the 
un/talented then RTM gives reasons to think that resources will be used more effectively and this could translate to better operational efficiency. Also important is that the principles when taken together draw attention to the socio-political factors surrounding exclusive TM as a way of addressing core assumptions and potential downsides.

\section{Further research}

Several lines of research arise from this analysis. The TM-performance link, although widely assumed, has not been demonstrated convincingly and requires more attention. The key challenge in establishing robust connections is measuring the extent to which organizations are running talent programmes as distinct from good HRM. Some measure of TM implementation is necessary and a generic measurement scale may have value (eg., see Jayaraman et al., 2018; Son et al., 2018). Further questions surround the choice of appropriate output measures although this is less problematic as a range of individual-level and organizational-level measures is available. Even if measurement difficulties can be overcome, however, a fundamental question remains concerning the extent to which people identified as talented really are more talented than those who are overlooked. Hence, as well as measuring the extent of TM implementation, ideally there should be some account of the actual talent possessed by people in talent programmes in relation to people who are excluded. This is necessary to overcome the possibility that similar results might accrue from near random selection of employees to populate talent pools.

No conflict of interest was declared in the production of this article.

\section{References}


Adebola, S. (2019), "Why do organizations run talent programmes? Insights from UK organizations", in Adamsen, B. and Swailes, S. (Eds), Managing talent: Understanding critical perspectives, Palgrave Macmillan, Basingstoke, pp.187-213.

Adler, S., Campion, M., Colquitt, A., Grubb, A., Murphy, K., Ollander-Krane, R. and Pulakos, E. (2016), “Getting rid of performance ratings: Genius or folly? A debate”, Industrial and Organizational Psychology, Vol. 9 No. 2, pp. 219-252.

Aguinis, H., Gottfredson, R.K., and Joo, H. (2012), "Using performance management to win the talent war", Business Horizons, Vol. 55 No. 2, pp. 609-616.

Baker, J. and Wattie, N. (2018), "Innate talent in sport: Separating myth from reality", Current Issues in Sport Science, No. 3, doi 10.15203/CISS_2018.006

Blass, E. (2007), Talent management. Maximising talent for business performance, Chartered Management Institute, London.

Borland, J. H. (1997), "The construct of giftedness", Peabody Journal of Education, Vol. 72 No. 3/4, pp. 6-20.

Borland, J.H. (2005), “Gifted education without gifted children”, in Sternberg, R.J. and Davidson, J.E. (Eds), Conceptions of giftedness, $2^{\text {nd }}$ Ed., Cambridge University Press, Cambridge, pp. 1-19.

Boštajančič, E and Slana, Z. (2018), “The role of talent management comparing mediumsized and large companies - Major challenges in attracting and retaining talented employees", Frontiers in Psychology, Vol. 9, Article 1750, doi 10.3389/fpsyg.2018.01750 Callahan, C.M. (1997), “The construct of talent”, Peabody Journal of Education, Vol. 72 No. 3/4, pp. 21-35. 
Collings, D.G. (2015), "The contribution of talent management to organizational success", in Kraiger, K., Passmore, J., dos Santos, N.R. and Malvezzi, S. (Eds), The Wiley

Blackwell Handbook of the Psychology of Training, Development and Performance Improvement, Wiley-Blackwell, Chichester, pp. 247-260.

Collings, D.G., Cascio, W.F. and Mellahi, K. (2017), “Introduction”, in Collings, D.G., Mellahi, K. and Cascio, W.F. (Eds), The Oxford Handbook of Talent Management, Oxford University Press, Oxford, pp. 3-22.

Collings, D.G. and Mellahi, K. (2009), "Strategic talent management: A review and research agenda", Human Resource Management Review, Vol. 19 No. 4, pp. 304-313.

Combs, J., Liu, Y., Hall, A., and Ketchen, D. (2006), "How much do high-performance work practices matter? A meta-analysis of their effects on organizational performance", Personnel Psychology, Vol. 59 No. 3, pp. 501-528.

Dalal, D.K. and Nolan, K.P. (2009), "Using dark side personality traits to identify potential failure", Industrial and Organizational Psychology, Vol. 2 No. 4, pp. 434-436.

Daubner-Siva, Ybema, S., Vinkenburg, C.J., and Beech, N. (2018), “The talent paradox: talent management as a mixed blessing”, Journal of Organizational Ethnography, Vol. 7 No. 1, pp. 4-86.

De Boeck, G., Meyers, M.C., and Dries, N. (2018), "Employee reactions to talent management: Assumptions versus evidence”, Journal of Organizational Behavior, Vol. 39 No. 2, pp. 199-213.

Derr, C., Jones, C. and Toomey, E. (1988), “Managing high-potential employees: current practices in thirty-three U.S. corporations", Human Resource Management, Vol. 27 No. 3, pp. 273-292. 
Dooher, M.J. and Marquis, V. (Eds) (1952), The development of executive talent, American Management Association, New York.

Dries, N. and De Gieter, S. (2014), "Information asymmetry in high potential programs. A potential risk for psychological contract breach", Personnel Review, Vol. 43 No. 1, pp. 136162.

Eden, D. (1984), “Self-fulfilling prophecy as a management tool. Harnessing Pygmalion”, Academy of Management Journal, Vol. 9 No. 1, pp. 64-73.

Ellington, J.K. and Wilson, M.A. (2017), “The performance appraisal milieu: A multilevel analysis of context effects in performance rating", Journal of Business and Psychology, Vol.32 No. 1, pp. 87-100.

Ehrnrooth, M., Björkman, I., Mäkelä, K., Smale, A., Sumelius, J. and Taimitarha, S. (2018), "Talent responses to talent status awareness - Not a question of simple reciprocation", Human Resource Management Journal, Vol. 28 No. 3, pp. 443-461.

Farndale, E. and Paauwe, J. (2007), “Uncovering competitive and institutional drivers of HRM practices in multinational corporations", Human Resource Management Journal, Vol. 17 No. 4, pp. 355-375.

Festing, M., Kornau, A. and Schafer, L. (2015), “Think talent - think male? A comparative case study analysis of gender inclusion in talent management practices in the German media industry", International Journal of Human Resource Management, Vol. 26 No. 6, pp. 707732.

Florida, R. (2002), “The economic geography of talent”, Annals of the Association of American Geographers, Vol. 92 No. 4, pp. 743-755. 
Florida, R. and Mellander, C. (2018), “Talent, skills and urban economies”, in. Clark, G., Feldman, M. Gertler, M. and Wojcik, D. (Eds), The new Oxford handbook of economic geography, Oxford University Press, Oxford, pp. 499-518.

Ford, J. (2005), “Examining leadership through critical feminist readings”, Journal of Health Organization and Management, Vol. 19 No. 3, pp. 236-251.

Gagne, F. (2013), “Yes, giftedness (aka 'innate' talent) does exist!”, in Kaufmann, S.B. (Ed.) The complexity of greatness. Beyond talent or practice, Oxford University Press, Oxford, pp. $191-221$.

Gallardo-Gallardo, E., Dries, N. and Gonzalez-Cruz, T.F. (2013), "What is the meaning of talent at work?", Human Resource Management Review, Vol. 23 No. 4, pp. 290-300.

Gallardo-Gallardo, E., Nijs, S., Dries, and Gallo, P. (2015). “Towards an understanding of talent management as a phenomenon-driven field using bibliometric and content analysis", Human Resource Development Review, Vol. 25 No. 3, pp. 264-279.

Garavan, T., O’Brien, F., and Watson, S. (2015), “Leadership development and organizational success", in Kraiger, K, Passmore, J., dos Santos, N.R. and Malvezzi, S. (Eds), The Wiley Blackwell Handbook of the Psychology of Training, Development and Performance Improvement, Wiley-Blackwell, Chichester, pp. 354-397.

Gelens, J., Dries, N., Hofmans, J. and Pepermans, R. (2013), “The role of perceived organizational justice in shaping the outcomes of talent management: A research agenda”, Human Resource Management Review, Vol 23 No. 4, pp. 341-353.

Glaister, A., Karacay, G., Demirbag, M., and Tatoglu, E. (2018), "HRM and performance The role of talent management as a transmission mechanism in an emerging market context”, Human Resource Management Journal, Vol. 28 No. 1, pp. 148-166. 
Green, S. (1989), "Emile Durkheim on human talents and two traditions of social justice", British Journal of Sociology, Vol. 40 No. 1, pp. 97-117.

Grimland, S., Vigoda-Gadot, E. and Baruch, Y. (2012), "Career attitudes and success of managers: the impact of chance event, protean and traditional careers", International Journal of Human Resource Management, Vol. 23 No. 6, pp. 1074-1094.

Hambrick, D.Z., Ullén, F. and Mosing, M. (2016), “Is innate talent a myth?”, Scientific American, 20 ${ }^{\text {th }}$ September. Available at www.scientificamerican.com (accessed 1 April 2020).

Hammett, P. (2008), "The paradox of gifted leadership: developing the generation of leaders", Industrial \& Commercial Training, Vol. 40 No. 1, pp. 3-9.

Henson, R.M. (2009), "Key practices in identifying and developing potential”, Industrial and Organizational Psychology, Vol 2 No. 4, pp. 416-419.

Howe, M., Davidson, J. and Sloboda, J. (1998), “Innate talents: Reality or myth?”, Behavioural and Brain Sciences, Vol. 21 No. 3, pp. 399-442.

Ingram, N. and Allen, K. (2019), “'Talent spotting' or 'social magic’? Inequality, cultural sorting and constructions of the ideal graduate in elite professions", The Sociological Review, Vol. 67 No. 3, pp. 723-740.

Jayaraman, S., Talib, P., and Khan, A.F. (2018), "Integrated talent management scale: Construction and initial validation”, SAGE Open, July-September, 1-12, doi $10.1177 / 2158244018780965$.

Jerusalim, R. and Hausdorf, P. (2007), “Managers' justice perceptions of high potential identification”, Journal of Management Development, Vol. 26 No. 10, pp. 933-950. 
Joo, H., Aguinis, H. and Bradley, K.J. (2018), "Not all nonnormal distributions are created equal: Improved theoretical and measurement precision". Journal of Applied Psychology, Vol. 102 No. 7, pp. 1022-1053.

Joyce, W.F., and Slocum, J.W. (2012), “Top management talent, strategic capabilities and firm performance", Organizational Dynamics, Vol. 41 No. 3, pp. 183-193.

Kaufman, S.B. (2013), "What is talent - and can science spot what we will be best at?", The Observer, 7th July. Available at https://www.theguardian.com/science/2013/jul/07/canscience-spot-talent-kaufman (accessed 1 February 2020).

King, K.A. (2015), “Global talent management”, Journal of Global Mobility, Vol. 3 No. 3, pp. 273-288.

King, K.A. (2017), The talent climate: Creating an organizational context supportive of sustainable talent development through implementation of a strong talent system, Journal of Organizational Effectiveness People and Performance, Vol. 4 No 4, pp. 298-314.

Latukha, M. (2018), “Talent development and a firm's performance: Evidence from Russian companies", Journal of General Management, Vol. 43 No. 2, pp. 51-62.

Latukha, M., and Veselova, A. (2018), “Talent management, absorbtive capacity, and firm performance: Does it work in China and Russia”, Human Resource Management, Vol. 58 No. 5 , pp. 503-519

Makarem, Y., Metcalfe, B.D. and Afiouni, F. (2019), “A feminist poststructuralist critique of talent management: Toward a more gender sensitive body of knowledge", Business Research Quarterly, Vol. 22 No. 3, pp. 181-193. 
ManpowerGroup (2018). Solving the talent shortage. Available at, https://www.manpowergroup.co.uk/wpcontent/uploads/2018/07/MG TalentShortage2018.pdf (accessed 24 April 2020). Mills, C.W. 1956 [2000], The Power Elite, Oxford University Press, Oxford. Murphy, K.R., Balzer, W.K., Lockhart, M.C. and Eisenman, E.J. (1985), "Effects of previous performance on evaluations of present performance", Journal of Applied Psychology, Vol. 70 No. 1, pp. $72-84$.

Murphy, C.W., Shleifer, A. and Vishny, R.W. (1991), “The allocation of talent: implications for growth", The Quarterly Journal of Economics, Vol. 106 No. 2, pp. 503-530.

Noon, M. (2018), "Pointless diversity training: Unconscious bias, new racism and agency", Work, Employment \& Society, Vol. 32 No. 1, pp. 198-209.

O’Connor, E.P. and Crowley-Henry, M. (2019), "Exploring the relationship between exclusive talent management, perceived organizational justice and employee engagement: Bridging the literature", Journal of Business Ethics, Vol. 156 No. 4, pp. 903-917.

Oxford Economics (2012), Global talent 2021. Oxford Economics, Oxford.

Painter-Morland, M., Kirk, S., Deslandes, G. and Tansley, C. (2019), “Talent management: The good, the bad and the possible”, European Management Review, Vol. 16 No. 1, pp. 135146.

Parekh, G., Brown, R.S., and Robson, K. (2018), "The social construction of giftedness: The intersectional relationship between whiteness, economic privilege and the identification of gifted”, Canadian Journal of Disability Studies, Vol. 7 No. 2, pp. 1-32. 
Peteriglieri, J. and Peteriglieri, G. (2017), “The talent curse. Why high-potentials struggle and how they can grow through it", Harvard Business Review, Vol. 95 No. 3, pp. 89-94.

Pfeffer, J. and Sutton, R.I. (2006), “Management half-truths and nonsense: How to practice evidence-based management”, California Management Review, Vol. 48 No. 3, pp. 77-100.

Pluchino, A., Biondo, A.E. and Rapisarda, A. (2018), “Talent vs luck: the role of randomness in success and failure”, Advances in Complex Systems, Vol. 21 No. 3/4, pp. 1-28.

Pruis, E. (2011), “The five key principles for talent development”, Industrial and Commercial Training, Vol. 43 No. 4, pp. 206-216.

Rawls, J. (1971), A theory of justice, Harvard University Press, Boston.

Right Management (2014), Talent management: Accelerating business performance. Global trends, challenges and priorities. Available at www.manpowergroup.com (accessed 1 February 2020).

Robinson, C., Fetters, R., Riester, D. and Bracco, A. (2009), “The paradox of potential: A suggestion for guiding talent management discussions in organizations", Industrial and Organizational Psychology, Vol. 2 No. 4, pp. 413-415.

Rosette, A.S., Koval, C.Z., Ma, A. and Livingston, R. (2016), "Race matters for women leaders: Intersectional effects on agentic deficiencies and penalties", The Leadership Quarterly, Vol. 27 No. 3, pp. 429-445.

Ross, S. (2013), “Talent derailment: a multi-dimensional perspective for understanding talent”, Industrial and Commercial Training, Vol. 45 No. 1, pp. 12-17.

Rotolo, C., Church, A.H., Smither, J.W., Colquitt, A.L., Shull, A.C., Paul, K.B. and Foster, G. (2018), "Putting an end to bad talent management: A call to action for the field of 
industrial and organizational psychology", Industrial and Organizational Psychology, Vol. 11 No. 2, pp. 176-219.

Saridakis, G., Lai, Y. and Cooper, C.L. (2017), "Exploring the relationship between HRM and firm performance: A meta-analysis of longitudinal studies”, Human Resource Management Review, Vol. 27 No. 1, pp. 87-96.

Scherer, R.F., Owen, Crystal, L. and Brodzinski, J.D. (1991), "Rater and ratee sex effect on performance evaluations in a field setting: A multivariate analysis", Management Communication Quarterly, Vol. 5 No. 2, pp. 174-191.

Schuler, R.S., Jackson, S.E. and Tarique, I. (2011), “Global talent management and global talent challenges: Strategic opportunities for IHRM”, Journal of World Business, Vol. 46 No. 4, pp. 506-516.

SHRM (2019). The global skills shortage. Society for Human Resource Management. Available at www.shrm.org (accessed 1 February 2020).

Silzer, R. and Church, A.H. (2009), "The pearls and perils of identifying potential”, Industrial and Organizational Psychology, Vol. 2 No. 4, pp. 277-412.

Simonton, D.K. (1999), “Talent and its development: An emergenic and epigenetic model”, Psychological Review, Vol. 106 No. 3, pp. 435-467.

Simonton, D.K. (2017), “Does talent exist? Yes”, in Baker, J., Cobley, S., Schorer, J. \& Wattie, N. (Eds). Routledge Handbook of Talent Identification and Development in Sport, Routledge, London, pp. 9-18.

Smith, L.M. and Campbell, J. (2012), Families, Education and Giftedness. Case studies in the construction of high achievement, Sense Publishers, Rotterdam. 
Son, J., Park, O., Bae, J., and Ok, C. (2018), “Double-edged effect of talent management on organizational performance: The moderating role of HRM investments", International Journal of Human Resource Management. doi 10.1080/09585192.2018.1443955

Strenze, T. (2013), "Allocation of talent in society and its effect on economic performance", Intelligence, Vol. 41 No. 3, pp. 193-202.

Sumelius, J., Smale, A. and Yamao, S. (2020), "Mixed signals: Employee reactions to talent status communication amidst strategic ambiguity", International Journal of Human Resource Management, Vol. 31 No. 4, pp. 511-538.

Swailes, S. (2013), "The ethics of talent management", Business Ethics: A European Review Vol 22 No. 1, pp. 32-46.

Swailes, S. and Blackburn, M. (2016), "Employee reactions to talent pool membership", Employee Relations, Vol. 38 No. 1, pp. 112-128.

Swailes, S. (2020), "Social and natural constituents of talent: A critical appreciation", in Swailes, S. (Ed.), Managing Talent: A critical appreciation, Emerald, Bradford, pp.13-31.

Swailes, S., Downs, Y., and Orr, K. (2014), "Conceptualising inclusive talent management: potential, possibilities and practicalities", Human Resource Development International, Vol 17 No. 5, pp. 529-544.

Szymanska, I. and Rubin, B. (2018), "Gender and relationship differences in the perceptions of male and female leadership", Gender in Management, Vol. 33 No. 4, pp. 254-281.

Thunnissen, M. and Gallardo-Gallardo, E. (2019), "Rigor and relevance in empirical TM research: Key issues and challenges”, Business Research Quarterly, Vol. 22 No. 3, pp.171180. 
Tsui, A.S. and Bruce, B. (1986), "Interpersonal affect and rating errors", Academy of Management Journal, Vol. 29 No. 3, pp. 586-599.

Ward, P., Belling, P., Petushek, E. and Ehrlinger, J. (2017), “Does talent exist? A reevaluation of the nature-nurture debate", in Baker, J., Cobley, S., Schorer, J. and Wattie, N. (Eds), Routledge Handbook of Talent Identification and Development in Sport, Routledge, London, pp.19-34.

Wayne, S.J. and Liden, R.C. (1995), "Effects of impression management on performance ratings", Academy of Management Journal, Vol. 38 No. 1, pp. 232-250.

Zesik, B. (2020), “The rhetoric, politics and reality of talent management: Insider perspectives", in Swailes, S. (Ed.), Managing Talent: A critical appreciation, Emerald, Bradford, pp. 51-69.

Zivnuska, S., Kacmar, K.M., Witt, L.A., Carlson, D.S. and Bratton, V.K. (2004), “Interactive effects of impression management and organizational politics on job performance", Journal of Organizational Behavior, Vol. 25 No. 5, pp. 627-640. 